\title{
Parliamentary Co-Evolution: National Parliamentary Reactions to the Empowerment of the European Parliament
}

Thomas Winzen

Christilla Roederer-Rynning

Frank Schimmelfennig

\begin{abstract}
Existing research on the European Union's (EU) multilevel parliamentary system builds on the hypothesis of parallel evolution, situating explanations for European Parliament (EP) empowerment at the EU level and explanations for national parliamentary powers in EU affairs at the national level. We propose the hypothesis of co-evolution, which specifies a connection between national and European arenas of parliamentarisation. We study whether the EP's empowerment enhances or reduces pressure on national parliaments to strengthen their own EU-related competences. First, we argue that national parliamentary parties take conscious positions on the powers of the EP. Second, support for the EP among the party composition of national parliaments tells us whether parliaments regard the EP as a competitor or ally, feeling pressed, or relieved of the pressure, to strengthen their EU-related competences.
\end{abstract}

\section{Key words}

Demoi-cracy, European Integration, European Parliament, National Parliaments.

\section{Introduction 1}

A demoi-cratic political system provides institutions and procedures for the representation of both individual citizens and statespeople. Representation in the European Union (EU) has evolved in this direction. The European Parliament (EP) has changed from a consultative, indirectly elected assembly into a directly elected powerful legislator (e.g. Rittberger 2005). Similarly, national parliaments have 
gradually created committees to monitor integration, information rights and ways to limit governments' freedom in Brussels (Raunio \& Hix 2000; Winzen 2012). These developments at the European and national levels have created the EU's "multilevel parliamentary field" or system (Crum \& Fossum 2009).

In order to advance the empirical-analytical research agenda on "demoi-cratization", we focus on what explains the evolution of the multilevel parliamentary system. Since national and European democratic institutions co-exist in a demoi-cracy, it is especially pertinent to investigate the conflicts and complementarities between them (see also Crum \& Fossum 2009). Yet, the dominant approach to explaining the EU's parliamentary system relies on what we may call the hypothesis of parallel or decoupled evolution. Existing studies analyse the evolution of the EP and national parliaments separately. For instance, the empowerment of the EP has been connected to policy goals of (a powerful coalition of) member states (Bräuninger et al. 2001: 50), the EP's success in capturing informal gains in day-to-day decision-making (Stacey \& Rittberger 2003; Farrell \& Héritier 2003), or reforms designed to compensate for the weakening of indirect democratic legitimacy in the course of European integration (Rittberger \& Schimmelfennig 2006; Schimmelfennig 2010). However, there is no evidence that the EP or the member states take account of developments at the level of national parliaments when asking for or granting new powers to the EP. In turn, the literature shows that national parliaments have created stronger oversight institutions in EU affairs in reaction to the deepening of integration, party political conflict over the EU, popular Euroscepticism and domestic parliamentary strength (Raunio \& Hix 2000; Saalfeld 2005; Winzen 2013; Karlas 2012). Yet, no study examines whether national parliaments react systematically to EP empowerment. Overall, the only factor that currently connects European and national arenas of parliamentarisation is the deepening of European integration.

We rely on what we may call the hypothesis of co-evolution, which aims to shed light on the connection between national and European arenas of parliamentarisation in the EU. In general, the hypothesis of co-evolution draws inspiration from the multilevel governance approach that starts 
from the premise that European integration disperses authority over actors at multiple levels (Marks et al. 1996). Thus, in order to capture important developments in European integration, such as the evolution of the EU's parliamentary system, it does not suffice to look exclusively at the European or national levels. Such an approach does neither imply the irrelevance of domestic explanations of national parliamentary empowerment, nor of EU level explanations for EP empowerment. Furthermore, the multilevel governance approach does not imply that domestic and European arenas of parliamentarisation are necessarily interdependent, yet it draws attention to this possibility (cf. Crum \& Fossum 2009). The hypothesis of co-evolution maintains that there actually is a connection between the institutional development of the EP and national parliaments in European integration, and it specifies this connection.

We suspect that domestic and European parliamentarisation are interdependent because the EP and national parliaments co-exist in the same political environment. They share a common focus on democratic representation in the EU's "multilevel parliamentary field" (Crum \& Fossum 2009). Yet, while they may both focus on democratic representation, they do so in part vis-à-vis the same electorate, which might allow one institution to compensate for the other's weakness or lead to institutional competition. The EP and national parliaments also exercise authority regarding a shared universe of policy decisions, and their members come from the same countries and parties. This opens up the possibility to compensate for domestic losses of parliamentary authority with European gains. Yet, party members focussing on national politics may also be wary of power shifts as a result of European parliamentarisation. Finally, national parliaments have to ratify changes in the EU's institutional design including decisions to empower the EP. Thus, they get the explicit opportunity to consider their position towards EU parliamentarisation. Moreover, national parliaments have regularly contemplated domestic reforms in order to balance the authority losses from treaty changes. It is at least conceivable that their evaluations of EU parliamentarisation play a role in domestic reform choices. 
In this paper we focus on one side of the interdependent process of parliamentarisation in the EU's multi-level system: the reactions of national parliaments to the empowerment of the EP. National parliaments are likely to be the drivers of co-evolution. For the EP it is much more difficult to adjust its demands for empowerment to national parliaments: with now 28 member states, the EP will rather rely on generic constitutional arguments such as that majority voting in the Council has to be tied to co-decision (Rittberger \& Schimmelfennig 2006). National parliaments, in turn, have only one European level parliament to take into account.

Our argument has two parts, which structure both the theoretical and empirical analyses. We begin at the micro-level of parliamentary parties. We argue that parliamentary parties take conscious positions towards the EP. In particular, support for parliamentarisation at the European level depends on parties' cultural conservatism (see also Hooghe et al. 2002). If parties did not take conscious positions on the EP, we would have to wonder whether the EP's development could have any effects on national institutional choice.

In a second step, we move to the institutional level of parliament. Here we seek to show that parliamentary evaluations of the EP have an effect on parliamentary oversight institutions in addition to existing explanations. We argue that aggregate institutional support for the EP tells us where national parliaments are on a continuum from competitive to cooperative parliamentarisation of the EU's multilevel system. In competitive parliamentarisation, national parliaments feel pressure to counteract the empowerment of their supranational counterpart. In cooperative parliamentarisation, EP empowerment does not produce, or even reduces, the pressure for national parliaments to play a strong role in EU decision-making.

\section{Parliamentary party support for the European Parliament}

The hypothesis of co-evolution builds on the assumption that national parliaments take conscious positions on the powers of the EP. Yet, it is also possible that parliamentary positions merely reflect support or opposition to European integration. It is only plausible that national parliaments base 
institutional choices on their view of the EP under the condition that they hold conscious views about the EP in the first place.

In order to establish whether parliaments take conscious positions towards the powers of the EP, we disaggregate "national parliaments" into the constituent parties. We do this because we conceive of collective parliamentary positions as aggregations of parliamentary party positions. We do not dispute that parliamentary party views of the EP depend significantly on their support for European integration. However, we argue that the question of how parties perceive the EP is not identical to the question of how they perceive European integration. There are explanations for parties' positions on the EP that work in addition to their support for European integration.

We believe this to be the case because a party's support for European integration is driven by its placement on two ideological dimensions: an economic left-right and a cultural liberal-conservative cleavage (also known as GAL-TAN). Since these two dimensions are correlated, we observe the wellknown "inverted-U" when we map party support for the EU on a general left-right dimension (Hooghe et al. 2002; Bakker et al. 2012). ${ }^{2}$ In contrast, following Hooghe and colleagues (2002), we argue that a party's support for the EP does not depend on its placement on the economic left-right dimension. Yet, it depends on the party's cultural liberalism or conservatism. Consequently, parties' support for European integration alone does not explain their support for the EP (the Appendix explains these arguments further). Hooghe and colleagues provide empirical support for these arguments for the year 1999 - we seek to show that the findings still hold.

H1: As we move from the culturally liberal to the culturally conservative end of the political space, party support for the European Parliament declines. 


\section{Parliamentary support for the European Parliament and domestic institutional adaptation}

We have argued so far that parties take systematic positions on the EP. Yet, in order to substantiate our argument of co-evolution, we also need to explain why national parliaments' oversight institutions in EU affairs depend on their aggregate institutional views of the EP. The evidence below shows that party positions are stable over time. Aggregate institutional positions vary somewhat more due to shifts in parliaments' party make-up. Nevertheless, our arguments should mainly account for cross-national variation.

The null hypothesis is one of independent evolution. In this case, parliamentary positions on the EP have no impact on their institutional adaptation to integration. The null hypothesis is compatible with the existence of systematic positive and negative views of domestic parliaments of the EP. It only claims that there is no causal connection between parliamentarisation at the European and national level. There is co-existence, not co-evolution.

We propose the alternative hypothesis of co-evolution. At low levels of support for the EP, we get closer to a competitive logic that involves zero-sum institutional competition. The empowerment of the EP, a supranational competitor, generates pressure on national parliaments to take measures to protect their authority. They do so by creating oversight institutions that enhance their role in EU decision-making. At high levels of support for the EP, we get closer to a logic that allows institutional cooperation. National parliaments regard the EP as an ally rather than a competing institution and do not implement reforms in reaction to EP empowerment. The EP, as an alternative source of democratic legitimacy, may even reduce the need for domestic oversight institutions. As we explain further below, we expect the following:

H2: As we move from EP-friendly to EP-critical parliaments, domestic parliamentary oversight institutions become stronger. 
We briefly elaborate the two ideal-typical logics of parliamentarisation. To begin with, parliamentarians and parliaments opposed to the EP see it as a supranational competitor. Parliaments oppose giving powers to the EP because this collides with their ideological agenda (see above). The EP is yet another supranational institution that takes away competences of the Council, the institution of national governments. Moreover, it claims to engage in democratic representation, the core institutional competence of national parliaments. The latter, however, do not consider European parliamentarisation a plausible option to address the democratic deficit. In sum, national parliaments feel pressed to step up their own efforts to play a relevant role in EU decision-making to counteract the supranational competition and the weakening of national governments.

Parliaments that support the EP regard it as their supranational ally. The empowerment of the EP is compatible with national parliaments' ideological agenda. European parliamentarisation is a feasible institutional option to address the EU's democratic deficit. Therefore, the empowerment of the EP does at least not create, or even reduces, the pressure on national parliaments to play a strong role in EU decision-making themselves.

\section{Analysis}

We begin with parlgov data on parliament compositions (Döring \& Manow 2011). We use items from the Chapel Hill $(\mathrm{CH})$ surveys to operationalise cultural conservatism, the economic left-right dimension, party and parliamentary support for the European Parliament (Bakker et al. 2012; Hooghe et al. 2010; Steenbergen \& Marks 2007). Data on popular Euroscepticism come from the Eurobarometer. We use Winzen's (2013) measure of the strength of national parliamentary oversight institutions. We add a control variable to distinguish a party's support for the EP from its support for European integration in general (based on the $\mathrm{CH}$ surveys). A second categorical control variable distinguishes the time periods between EU treaty changes to capture the effect of the deepening of integration. Finally, we control for domestic parliamentary committee strength (Martin \& Depauw 
2011). For reasons of space, we have to refer to the Appendix (Table A1) for details on the operationalisation. Our data cover the years 1999-2010.

\section{Party support for the European Parliament}

A first examination of the data shows that European parties are "somewhat in favour" of the EP on average (average support is 4.8 on a 1-7 scale). Moreover, a party hardly ever changes its position. Regressing party support for the EP on its support in the previous year, we are able to explain 97 per cent of variation in the data. Thus, we have to explain differences between parties.

$$
\text { ---Table } 1 \text { about here--- }
$$

Table 1 presents our multivariate analysis of party support for the EP in 2010 (the Appendix shows models for 2006, 2002 and 1999 in Table A2, bivariate relationships in Figure A1 and robustness checks including additional control variables). Absent longitudinal variation, we model party support for the EP at four cross-sections corresponding to the waves of the $\mathrm{CH}$ expert surveys. We present the results for 2010 but, as the Appendix shows, the results for the other years do not differ. The first and second models respectively contain only the measures for cultural conservatism and economic left-right positions. The third model includes both measures. The fourth model adds a control for party support for European integration. The fifth model does not include party support for European integration but country dummy variables, meaning that the results reflect only differences between parties in a country.

We examine the results in the light of Hypothesis 1 suggesting that cultural conservatism depresses party support for the EP, controlling for party support for European integration. Cultural conservatism has a consistently significant effect. Substantively, based on Model 1, support for the EP declines by two points on the 1-7 scale as we move from extremely liberal to extremely conservative parties. Cultural conservatism still matters if we control for party support for integration in Model 4, although the impact is reduced. The effect of economic left-right positions is significant in 
some models, yet it is inconsistent, changes signs and lacks explanatory power if we examine the $r$ square values of the models (Figure A1 in the Appendix supports this impression visually).

In sum, in line with earlier evidence (Hooghe et al. 2002), cultural conservatism explains party support for the EP, even when controlling for party support for European integration. This finding gives us confidence that parties hold systematic positions on the EP.

The impact of support for the EP on national parliamentary oversight institutions

Figure $A 2$ in the Appendix shows average levels of parliamentary and governmental support for the EP in our data. There are clear cross-national differences. For instance, while British parliament and government take a "neutral" position, the Belgian, Greek and German parliaments are strong supporters. Figure A3 shows that there is a negative bivariate relationship between EP support and the strength of parliamentary oversight institutions in all individual years in our data.

\section{---Table 2 about here---}

Table 2 presents the multivariate analysis (the Appendix presents robustness checks). We do not have the option to analyse individual cross-sections with regression techniques because we have, at most, 27 cases per year. Instead, we present pooled models of the years 1999-2010. Model 1 includes only parliamentary support for the EP as explanatory variable. Models 2-4 gradually add existing explanations: a measure for the deepening of integration, for popular Euroscepticism and domestic committee strength. Model 5 additionally controls for parliamentary support for European integration. Model 6 adds a lagged dependent variable. The last model should be seen as robustness check only. There is not much variation over time in the data meaning that the effects of the remaining variables besides the lagged dependent variable are bound to be small.

As to the results, in line with Hypothesis 2 there is a consistently significant and substantially relevant negative effect of parliamentary support for the EP on the strength of oversight institutions. A oneunit increase on the 1 to 7 scale for EP support corresponds to a .2 unit decline on the 0 to 2 scale for 
the strength of oversight institutions. If we control for parliamentary support for European integration, the effect of EP support remains stable, albeit significant only at the .1 level. Support for European integration is not significant. The effect of EP support is the only one that holds in the model with a lagged dependent variable although it becomes substantially very small.

Although none of the control variables retains a significant effect in Model 6, there are such effects in the other models. We observe significantly stronger oversight institutions in later treaty phases. Moving from post-Amsterdam to post-Lisbon corresponds to about a .3 increase in the index of oversight institutions, based on Model 2. We note, however, that the adaptation phase to Lisbon might have continued beyond the period when our data collection on oversight institutions ended (mid-2010). We find an effect of Euroscepticism (e.g. Raunio 2005). Yet, this effect is weakly significant and only major differences matter. For instance, we expect a .25 unit difference in oversight institutions between, on one side, a country with equally large Europhile and Eurosceptic groups of voters and, on the other side, a country with a 50 percent excess of Eurosceptics. Finally, a move from the parliament with the weakest domestic committees observed in our data to the strongest corresponds to about a .5 unit increase in the strength of oversight institutions in EU affairs (e.g. Karlas 2012).

Summing up, the previous section showed that parliamentary parties take systematic positions on the EP. This section aggregated parliamentary party positions to the institutional level. The descriptive analysis and regression models show that there are weaker oversight institutions in EU affairs in parliaments that support the EP compared to parliaments that oppose the EP. This finding does not mean, as we have also seen, that prevailing explanations for national parliaments' institutional adaptation to integration lose relevance. However, in addition to prevailing explanations, the extent to which national parliaments adopt strong oversight institutions in EU affairs also depends on their support for Europe's supranational parliament. 


\section{Case studies}

We complement the quantitative results with two case studies. Our approach is to probe the plausibility of the arguments about party positions on the EP, and about the link between such positions and parliamentary reform in EU affairs. First, in a 2003-2004 reform in Denmark, a rather EP-critical parliament, we expect to observe the scenario of competitive parliamentarisation. Second, we examine debates on EU treaty reform in the 2000s in Germany's EP-friendly parliament, expecting to observe that parliamentarisation at the European level does not create pressure for domestic oversight. In each case study, we briefly outline key elements of parliamentary reform in EU affairs in the last decade; then, we probe the plausibility of the arguments developed above, first focusing on the institutional level of analysis, then turning to the micro-level of parliamentary parties.

\section{Denmark}

On average, Danish parties have been comparatively critical of the EP (see Figure A2) and allegedly see the national parliament as the core source of legitimacy (Katz \& Wessels 1999; Wind 2009). In turn, the Danish parliament's system of domestic oversight is one of the (reputedly) strongest and best-known across the EU. Yet, while popular Euroscepticism and national parliamentary strength explain this in part, there is little systematic knowledge about how Danish parliamentarians perceive, and have responded to EP empowerment.

Key elements of the reform. In 2003-2004 the Danish parliament (Folketinget) passed a larger reform of its EU-oversight institutions. The 2004 reform identified a broad range of issues to be addressed-in all, nine-which is not surprising given the general thrust of the process. The more important changes concerned: a more systematic involvement of specialist committees in scrutinizing EU legislation; new commitments by the Danish government to provide detailed and continuous information on EU legislation; and, finally, the formalization of cooperation between members of Folketinget and (Danish) members of the EP. All measures were described in a wealth of 
practical and organizational details, and often supported by evidence from Finland, Sweden, and the UK.

Institutional level. The justification for change identified by the architects of the reform provides important clues on the motivations of Danish parliamentarians (Europaudvalget 2004). It was twofold. The first reason concerned the practice of codecision. The report singled out the significant increase in the number of so-called "first-reading" agreements between the European Parliament and the Council-allegedly affecting 30 to $40 \%$ of all legislative proposals at the time of reform-as an important development, raising new requirements for the organization of Danish parliamentary control over EU affairs. In light of this development, the authors of the report argued, it was "fundamental that Folketinget be involved as early as possible in EU policy-making in order to be able to exert maximal influence on the decisions adopted in the EU" (Europaudvalget 2004, 5; added emphasis). The other important reason was the prospect for national parliaments to be granted formal competences in monitoring the principle of subsidiarity, as envisioned in the Constitutional Treaty. Anticipating ratification, Danish parliamentarians wished "already now, and in line with the European Affairs Committees of several other national parliaments, to make an optimal use of these new opportunities" (Europaudvalget 2004, 2; added emphasis). On both accounts, it was clear that: Danish parliamentarians were well aware of deepened integration; they reformed domestic institutions in response to-sometimes in anticipation of-these changes; and finally, they aimed to compensate the perceived losses in the bargaining power of Folketinget. In the mid-2000s, rescuing Folketinget involved not just the mobilization of domestic parliamentary actors but also the enrolment of Danish MEPs.

We do not dispute the effect of the deepening of integration. Yet, did reservations about the powers of the EP also motivate parliamentary reform? Working documents from the European Affairs Committee are silent on this point, but we can flesh out the Danish imagery surrounding the EP and EP empowerment from attendant parliamentary debates and the broader public debate on EU 
affairs. Occasionally, Danish parliamentarians expressed their evaluations of the EP publicly in these arenas.

Party level. In the parliamentary arena, the debates focused on the new partisan alignment on EU affairs agreed on 2 November $2004 .^{3}$ The parties in government hailed this agreement as an historic opportunity to transcend the "yes-no" cleavage and develop a more nuanced debate on EU institutions: indeed, departing from its longstanding Eurosceptic platform (Nielsen \& Pedersen 2012), the Socialist People's Party had joined the coalition of "EU-constructive" parties in favor of the ratification of the Constitutional Treaty. Although the debate continued to be structured around a broad "yes"-"no" axis, some nuances appeared as Eurosceptic MPs pressed individual EUconstructive parties to justify their position. "Yes" parties tended to highlight EP empowerment as one of the reasons-sometimes one of the most important-for supporting the Constitutional Treaty. While all "yes" parties emphasized the democratic advances secured in the Constitutional Treaty, the Liberals in government tended to emphasize the tangible policy benefits to be expected from EP empowerment, ${ }^{4}$ and the Social-Democrats and the Social Liberals the democratic gains. ${ }^{5}$ "No" parties, on the other hand, opposed transferring more powers to the EP and listed EP empowerment as a reason for rejecting the Constitutional Treaty partly. ${ }^{6}$ The Danish People's Party viewed EP empowerment as hollowing out the legislative sovereignty of Folketinget. ${ }^{7}$ Both the Unity List and the Danish People's Party referred sarcastically to the political agreement of 2 November 2004 as a "national compromise," alluding to a collusion of the elite against the people.

Outside the parliamentary arena, Danish politicians were occasionally compelled to spell out publicly their evaluation of the EP. The EP hearings with the Commissioners designate that took place in the fall of 2004 provided them with just such an imperative; they also illustrate how nuances in the parliamentary debate give way to a more vivid EU debate in the Danish media. The trigger of public controversy was the EP's unprecedented refusal to endorse the team of Commissioners presented by Commission president-elect Barroso, at the end of October 2004. This controversy split the Danish "EU-constructive" coalition: left-wing parties supported the EP's show of strength; liberal and 
conservative parties criticized it. To some extent, these divisions reflected the fact that a predominantly Socialist EP had weakened a liberal Commission. ${ }^{8}$ However, divisions among "EUconstructive" parties also revealed more fundamental differences on their respective evaluations of the role of the EP. Among parties of the "yes" block, the conservatives were especially critical of EP activism. Conservative MEP Gitte Seeberg argued that "the EP has claimed power that is undesirable. This is not about Buttiglione. This is about power. I don't think the EP must have more power" (Gitte Seeberg, Politiken 28 October 2004). Several days later, she developed this argument in a full-length opinion piece entitled "Deliver us from EU parliamentarianism." Taking issue with Social-democratic MEP Poul Nyrup Rasmussen, who had "proudly called [the EP's action] a victory for democracy and a historic day for parliamentary forces in the EU" - she explained:

I do not support European parliamentarianism. We have a say in Denmark: nobody is above and beyond Folketinget. This is parliamentarianism. Foketinget can bring down governments and dismiss ministers. Folketinget can propose, adopt, and amend legislation. Folketinget is the beating heart of Danish democracy. Folketinget is the proof of our national independence. The European parliament shall neither approve nor bring down a government of the United States of Europe. The European Parliament shall not have the sovereign right to propose or adopt legislation. The European Parliament is an EU institution, side-by-side with the Commission and the Council of Ministers. Parliamentarianism belongs in states, not in the EU. (MEP Gitte Seeberg, (Fri os fra parlamentarisme i Europaparlamentet, Politiken, 12 November 2004).

As the public debate served to highlight, divergences on the role of the EP crisscrossed the "yes" coalition. For right-wing cultural conservatives, the EP was an institution inherently belonging to the realm of intergovernmental politics; for the Social-Democrats, the Social Liberals, and the Socialist People's Party, the EP was an additional arena for the unfolding of parliamentary politics. The prointegration camp did not display uniform views of the EP. 
In sum, at the party level, in line with our expectations (H1), there is evidence that partisan ideologies affect parties' perceptions of the European Parliament. This appeared most visibly in the fact that pro-integration parties' positions on the role of the EP clustered along the expected culturally liberal v. culturally conservative cleavage. At the institutional level, the connection between aggregate parliamentary support for the EP and institutional reform is not clear-cut. The Folketing emphasized domestic reform as a means to "exert maximal influence" on EU legislation. We also observe that some parties in the pro-EU coalition express reservations towards the powers of the EP in public debates at the time of the domestic reform. Yet, we do not directly observe the final link between such reservations and reform. Possibly, the parliament would have scaled down reform efforts if the conservative parties had been more supportive of the EP on average. Hence, the Danish case study supports $\mathrm{H} 1$ but does not yield conclusive evidence on the second step of our argument. It is clear, however, as we show in the second case study, that parliamentary motivations for domestic institutional reform are much less pronounced in Germany's strongly EP-friendly parliament compared to the Danish parliament.

\section{Germany}

The German parliament is one of the most supportive national parliaments in the EU both regarding European integration in general and the empowerment of the EP in particular (see Figure A2). In his 1996 European Representation Study, Bernhard Wessels finds that 60 percent of German MPs agree that the legitimacy of the EU should be based on the EP (country mean 35\%), whereas only 19 percent (country mean 37\%) consider national parliaments to be the appropriate source of democratic legitimacy in the Union (Wessels 2005: 452). In addition, a 2003 survey of German MPs shows that only 29 percent find that they have too little supervision of the positions of the German government in the Council (Wessels 2005: 461). Under these circumstances, it appears rather puzzling that the German parliament has comparatively strong oversight powers in EU affairs: in terms of formal powers, it is closer to the more Eurosceptic Nordic countries than to the Southern European parliaments whose EU- and EP-friendly attitudes it shares. 
Key elements of reform. Reforms of oversight powers in the Bundestag have been weak and incremental throughout the 2000s. The Bundestag extended its existing competences to new areas such as foreign and defense policy; it has upgraded the legal status of some provisions from agreement to law; it acquired more detailed information rights and more time to react to proposed EU legislation; and its involvement in amendments of primary law outside the normal national ratification procedure has been strengthened (Beichelt 2012: 147-50).

Institutional level. In marked contrast to Denmark, key reforms strengthening the oversight powers of the Bundestag have originated in rulings of the German Federal Constitutional Court and not in the parliament itself. In both its decisions on the Treaty of Maastricht (1993) and the Treaty of Lisbon (2009), the Court strengthened the role of the national parliament in EU affairs, going beyond the initial preferences of German parliamentarians (Beichelt 2012: 144-145, 149-150). Moreover, tellingly, the Bundestag has only implemented the Court's requirements in a minimalist fashion. The Court is thus the major solution to the German puzzle of strong support for the EP and strong oversight powers in the national parliament.

Party level. At the party level, we provide a summary analysis of the discursive links made by party representatives between the empowerment of the EP and national parliamentary oversight in Bundestag debates on the Constitutional Convention, the Constitutional Treaty and the Treaty of Lisbon from 2003 to $2009 .{ }^{9}$ Based on the findings of the comparative analysis above, we expect that German mainstream parties (Christian Democrats, Social Democrats, Greens, and Free Democrats) perceive no competition between the EP and the Bundestag and may even see the empowerment of the EP as a legitimate compensation for their own loss of influence. This expectation is broadly confirmed by the analysis of parliamentary debates on EU treaty reform between 2003 and 2009.

The representatives of mainstream EU-friendly parties perceive the further empowerment of the EP and national parliaments as envisaged by the Constitutional Treaty and Treaty of Lisbon as two aspects of a single and highly welcome process: the parliamentarization of the EU. ${ }^{10}$ They support the 
most far-reaching proposals for the strengthening of the EP and welcome the European Convention as a parliamentary method of treaty-making. ${ }^{11}$ There is further broad agreement on a cooperative relationship between the two levels of parliaments. For instance, Michael Roth (SPD) regards the Bundestag as a "partner of the European Parliament" and advocates a "division of labor". ${ }^{12}$ For Axel Schäfer (SPD), "we as a parliament are a part of Europe, exactly like our colleagues in Brussels ... They are not our opponents." ${ }^{13}$

Skepticism towards the EP and demand for stronger competences of the national parliament can only be found among the CSU and some members of the CDU. For the CSU, Edmund Stoiber, prime minister of Bavaria, claimed that, in the absence of a European public sphere, the EP "will never be a classical parliament" and cannot fully substitute national parliaments. ${ }^{14}$ By contrast, members of the CDU have made more conditional statements. Wolfgang Schäuble (CDU) justifies "the contribution of national parliaments" by the observation that "in the perception of most people ..., the European Parliament is not or not yet able to provide legitimacy for political-parliamentary decisions alone"; Gerd Müller (CDU) calls for a strong role of national parliaments because the loss of power of national parliaments is not fully compensated by additional powers of the EP. ${ }^{15}$ These mildly dissenting arguments from the culturally conservative end of the mainstream spectrum correspond to our hypothesis that culturally conservative parties are less likely to accept EP empowerment as a compensation for the loss of national parliamentary power $(\mathrm{H} 1)$.

Even in this mild form, such arguments are absent from the contributions of the FDP, the SPD, or the Greens to the debate. Members of the SPD explicitly rejected the "red card" option of subsidiarity control by national parliaments ${ }^{16}$, and Michael Roth (SPD) openly contradicted the opinion of the Constitutional Court about the EP as a parliament of inferior quality. ${ }^{17}$

Finally, the opposition of the Left part to the Treaty of Lisbon had mainly policy reasons. According to Lothar Bisky, the Left recognizes improvements such as the stronger codecision rights of the EP and the stronger participation of national parliaments but rejects the EU's security and defense policy as 
well as its "neoliberal" economic policies. ${ }^{18}$ The contributions of the Left to the debate provide exemplary support for the conjecture that support for the EP and opposition to European integration go together at the extreme left side of the political space.

In sum, even despite pressure of the Constitutional Court, the German parliament has not implemented major reforms in the 2000s. We have examined whether its views of the EP help explain this. The analysis of party discourse in parliament shows that the German parties position themselves towards the EP in line with our expectations, and that the Bundestag as a whole has a cooperative attitude towards the EP. Moreover, EP empowerment has been welcome and not generated pressure for reform.

Comparing the findings from the two case studies, we find evidence in favour of $\mathrm{H} 1$ in both cases. The degree of cultural conservatism of parliamentary parties helps to explain their views of the EP, beyond what can be explained by their views on European integration in general. Regarding $\mathrm{H} 2$, we observe significant parliamentary reforms in the EP-critical Danish parliament and weak ones in the EP-friendly German parliament: on the one hand, we have a parliament acting upon own initiative and seeking to maximize influence; and on the other hand, a parliament acting on the basis of Constitutional Court requirements and implementing these requirements in a minimalist fashion. The EP's empowerment has not generated any reform pressure in Germany. In Denmark, we observe reservations towards the EP among some parties of the pro-integration parliamentary majority but we cannot conclusively say whether these reservations contribute to the 2003-2004 reform efforts or not. Thus we cannot support or reject H2 in the Danish case. Overall, the case studies support H1. Support for $\mathrm{H} 2$ comes from the comparison between the two cases and the German parliamentary debate, while the Danish evidence is inconclusive.

\section{Conclusion}

The hypothesis of parliamentary co-evolution stipulates that parliaments at different levels of a multi-level system do not develop independently of each other but in co-evolution. The parties of 
which national parliaments are composed not only have systematic attitudes toward the EP but also act upon these attitudes in the creation of oversight institutions for EU affairs. The more strongly a parliament is composed of parties with a pro-EP attitude, the less it will regard the EP as a competitor or as an inadequate compensation for parliamentary deficits at the national level and the less it feels the need to counter the empowerment of the EP with the strengthening of national parliaments' oversight competences in EU affairs.

Turning to the results, our quantitative analyses show that culturally conservative parliamentary parties oppose EP empowerment. At the institutional level, parliaments that are more critical of parliamentarisation at the European level create stronger oversight institutions in EU affairs than their pro-EP counterparts. Two case studies of an EP-critical and an EP-friendly national parliament support, first, our analysis of the correlations between party ideology and positions towards EP empowerment. Second, in line with our expectations, the EP-critical Danish parliament implemented a significant reform in the mid-2000s whereas the EP-friendly German parliament made only "minimalist" changes. In Germany, almost all parties clearly welcome the EP's empowerment. Only the most conservative of the mainstream parties criticises the EP and connects such critique to an emphasis on the importance of national parliaments in the EU. We find EP-critical views among the pro-integration parties in Denmark but our evidence as to whether such views are linked to domestic parliamentary reform is not conclusive. In sum, we observe noteworthy evidence in favour of the coevolution hypothesis. We acknowledge that further empirical investigation at the level of case studies would be useful because at this level our evidence is weaker than in the quantitative analysis. Future research may also shed further light on the question whether the quantitative relationship that we find emerges mainly because EP-critical parliaments react competitively to supranational parliamentarisation, or because EP-friendly parliaments react cooperatively, or because, as we argue, both logics are at work.

The findings suggest that the development of a multilevel, demoi-cratic parliamentary system in the $\mathrm{EU}$ is the result of interdependent European and national parliamentarisation processes. While the 
deepening of supranational integration drives parliamentary empowerment at both levels, national parliaments also base their strategies on whether they see EP empowerment as a legitimate compensation for their authority losses. Support for the EP is high where parliaments are composed of culturally liberal parties which are open towards the idea of a European demos and political community. In turn, national parliaments are particularly strong where parliamentary parties have strong national identities and cultural demarcation preferences, and are critical of supranational parliamentarisation.

\section{Authors}

Christilla Roederer-Rynning is Associate Professor of Political Science (University of Southern Denmark). Thomas Winzen is post-doctoral researcher and Frank Schimmelfennig Professor of European Politics (both ETH Zurich). Correspondence: thomas.winzen@eup.gess.ethz.ch.

\section{Acknowledgements}

Frank Schimmelfennig and Thomas Winzen acknowledge financial support from the Swiss National Science Foundation in the context of the NCCR Democracy. Christilla Roederer-Rynning thanks the program on the "Reform of Welfare State Institutions" of the University of Southern Denmark for research support and Rasmus Jacobsen for assistance with data collection. For comments, we thank Stefanie Bailer, Achim Hurrelmann, Dirk Junge, Shane Martin, participants at the workshop "Demoicracy in the European Union" (ETH Zurich, November 2012), the Swiss Political Science Association's Annual Conference (University of Zurich, January 2013), the European Union Studies Association's Biannual Conference (Baltimore, May 2013), the workshop “Parliaments and Parliamentarians IV" (ETH Zurich, May 2013), the European Political Science Association General Conference (June 2013), and three anonymous reviewers for the Journal of European Public Policy.

\section{Notes}


${ }^{1}$ The online appendix can be found at: http://www.eup.ethz.ch/

${ }^{2}$ Earlier formulations of the "inverted-U" also suggested strategic reasons why marginal parties mobilise against European integration (Hooghe et al. 2002: 968-969). However, the lack of temporal variation in party positions (see below) and some recent evidence suggest that Euroscepticism at the margins is substantively motivated (Statham \& Koopmans 2009). Moreover, we focus on parliamentary parties that are not completely excluded from power.

${ }^{3}$ The immediate purpose of the November agreement was to harness an alternative parliamentary majority in support of the ratification of the Constitutional Treaty given that in EU matters, the minority Liberal-Conservative coalition in government could not rely on the support of its normal parliamentary ally, the Euroskeptical Danish People's Party. The agreement underpinned the 2004 reform of oversight institutions. It brought together the government (Liberals and Conservatives) and opposition parties (the Social-Democrats, the Social-Liberal Party (Radikale-Venstre) and the Socialist People's Party).

${ }^{4}$ For documentation of the debates, see http://www.ft.sk/samling/20041/forespoergsel/f14/beh1/forhandling.htm?startltem=-1\#alleindlæg. For example, "The fact that the EP will be more influential in agriculture means that we can expect animal welfare issues to become much more salient" (Charlotte Antonsen, member of the Liberal Party).

${ }^{5}$ Social-democratic Jakob Buksti: "For populations in European countries, it [i.e., the Constitutional Treaty] increases the transparency of EU decisions. The parliamentary control over EU decisions increases; the EP becomes more influential in EU policy-making; and the national parliaments will be more influential, individually and collectively. The EU becomes more democratic". Elisabeth Arnold, member of the Social Liberal Party: "The special things we wish to emphasize in the Constitutional Treaty are: a good description of the normative foundations of the EU, a clear division of labor, strengthened citizen rights, a strengthened European Parliament, and the involvement of national parliaments..." 
${ }^{6}$ These are the Danish People's Party on the right, and the Unity List on the left.

${ }^{7}$ Søren Krarup, member of the Danish People's Party: "What do we read in the new EU constitution? ... That the EP exercises the law-making and budget-making functions together with the Council of Ministers, chapter 19, paragraph 1. That's where parliamentary sovereignty went down the drain."

${ }^{8}$ Liberal MEP Karen Riis-Jørgensen: "Europe is weakened, and we have witnessed a 'no' to a very liberal Commission. There are two winners, from a liberal perspective: these are anti-EU forces and the Socialists, who now smell blood" (Politiken 28 October 2004).

${ }^{9}$ For documentation of the debates, see http://dipbt.bundestag.de/dip21.web/bt.

${ }^{10}$ Peter Hinze (CDU), Deutscher Bundestag, Plenarprotokoll 15/43, 8 May 2003, 3352-4;

Plenarprotokoll 15/175, 12 May 2005, 16378-9; Axel Schäfer (SPD), Deutscher Bundestag,

Plenarprotokoll 15/175, 12 May 2005, 16380; Thomas Silberhorn (CSU), Deutscher Bundestag, Plenarprotokoll 16/107, 4 July 2007, 10999; Plenarprotokoll 16/151, 13 March 2008, 15854.

${ }^{11}$ Deutscher Bundestag, Plenarprotokoll 15/43, 8 May 2003; Plenarprotokoll 15/53, 26 June 2003.

${ }^{12}$ Deutscher Bundestag, Plenarprotokoll 15/43, 8 May 2003, 3560; Plenarprotokoll 15/160, 24 February 2005, 14905.

${ }^{13}$ Deutscher Bundestag, Plenarprotokoll 16/232, 26 August 2009, 26263.

${ }^{14}$ Edmund Stoiber (CSU), Deutscher Bundestag, Plenarprotokoll 15/175, 12 May 2005, 16365.

${ }^{15}$ Gerd Müller (CDU), Deutscher Bundestag, Plenarprotokoll 15/53, 26 June 2003, 4340; 15/175, 12 May 2005, 16371; Wolfgang Schäuble (CDU), Deutscher Bundestag, Plenarprotokoll 15/160, 24 February 2005, 14917.

${ }^{16}$ Axel Schäfer and Michael Roth (both SPD), Deutscher Bundestag, Plenarprotokoll 16/103, 14 June 2007, 10580 and 10583.

${ }^{17}$ Deutscher Bundestag, Plenarprotokoll 16/233, 8 September 2009, 26357.

${ }^{18}$ Lothar Bisky (Die Linke), Deutscher Bundestag, Plenarprotokoll 16/157, 24 April 2008, 16461-2. 


\section{References}

Bakker, R., De Vries, C., Edwards, E., Hooghe, L., Jolly, S.K., Marks, G., et al. (2012) 'Measuring Party Positions in Europe: The Chapel Hill Expert Survey Trend File, 1999-2010', Party Politics.

Beichelt, T. (2012) 'Recovering Space Lost? The German Bundestag's New Potential in European Politics', German Politics 21(2): 143-160.

Bräuninger, T., Cornelius, T., König, T. and Schuster, T. (2001) 'The Dynamics of European Integration: a Constitutional Analysis of the Amsterdam Treaty', in G. Schneider and M. Aspinwall (eds.), The Rules of Integration, Manchester: Manchester University Press, pp. 46-68.

Crum, B. and Fossum, J.E. (2009) 'The Multilevel Parliamentary Field: a framework for theorizing representative democracy in the EU', European Political Science Review 1(2): 249-271.

Döring, H. and Manow, P. (2011) Parliament and government composition database (ParlGov): An infrastructure for empirical information on parties, elections and governments in modern democracies. Version 11/07 - 26 July 2011.

Europaudvalget (2004) Beretning om reform af Folketingets behandling af EU-sager. Beretning afgivet af Europaudvalget d. 10. December 2004.

Farrell, H. and Héritier, A. (2003) 'Formal and Informal Institutions Under Codecision: Continuous Constitution-Building in Europe', Governance 16: 577-600.

Hooghe, L., Bakker, R., Brigevich, A., De Vries, C.E., Edwards, E., Marks, G., et al. (2010) 'Reliability and validity of the 2002 and 2006 Chapel Hill expert surveys on party positioning', European Journal of Political Research 49(5): 687-703.

Hooghe, L., Marks, G. and Wilson, C.J. (2002) 'Does Left/Right Structure Party Positions on European Integration?', Comparative Political Studies 35(8): 965-989.

Karlas, J. (2012) 'National Parliamentary Control of EU Affairs: Institutional Design after Enlargement', West European Politics 35(5): 1095-1113. 
Katz, R.S. and Wessels, B. (eds.) (1999) The European Parliament, National Parliaments, and European Integration, Oxford: Oxford University Press.

Marks, G., Hooghe, L. and Blank, K. (1996) 'European Integration from the 1980s: State-Centric v. Multilevel Governance', Journal of Common Market Studies 34(3): 341-378.

Martin, S. and Depauw, S. (2011) 'The Impact of Multiparty Government on the Internal Organization of Legislatures', Paper presented at the 69th Annual National Conference of the Midwest Political Science Association, Chicago, 31 March - 3 April 2011.

Nielsen, R.L. and Pedersen, R.B. (2012) 'The Danish Left and the Constitutional/ Lisbon Treaty: From vote/office seekers to policy pragmatists', in M. Holmes and K. Roder (eds.), The Left and the European Constitution, Manchester: Manchester University Press, pp. 213-237.

Raunio, T. (2005) 'Holding governments accountable in European affairs: Explaining cross-national variation', The Journal of Legislative Studies 11(3-4): 319-342.

Raunio, T. and Hix, S. (2000) 'Backbenchers learn to fight back: European integration and parliamentary government', West European Politics 23(4): 142 - 168.

Rittberger, B. (2005) Building Europe's Parliament: Democratic Representation Beyond the Nation State, Oxford: Oxford University Press.

Rittberger, B. and Schimmelfennig, F. (2006) 'Explaining the constitutionalization of the European Union', Journal of European Public Policy 13(8): 1148 - 1167.

Saalfeld, T. (2005) 'Deliberate delegation or abdication? Government backbenchers, ministers and European Union legislation', Journal of Legislative Studies 11: 343-371.

Schimmelfennig, F. (2010) 'The normative origins of democracy in the European Union: toward a transformationalist theory of democratization', European Political Science Review 2(2): 211-233.

Stacey, J. and Rittberger, B. (2003) 'Dynamics of formal and informal institutional change in the EU', Journal of European Public Policy 10(6): 858 - 883. 
Statham, P. and Koopmans, R. (2009) 'Political party contestation over Europe in the mass media: who criticizes Europe, how, and why?', European Political Science Review 1(3): 435-463.

Steenbergen, M. and Marks, G. (2007) 'Evaluating Expert Surveys', European Journal of Political Research 46(3): 347-366.

Wessels, B. (2005) 'Roles and orientations of members of parliament in the EU context: Congruence or difference? Europeanisation or not?', The Journal of Legislative Studies 11(3): 446 - 465.

Wind, M. (2009) 'When Parliament comes first. The Danish Concept of Democracy Meets the European Union', Nordic Journal of Human Rights 27(2): 272-288.

Winzen, T. (2012) 'National parliamentary control of European Union affairs: a cross-national and longitudinal comparison', West European Politics 35(3): 657-672.

Winzen, T. (2013) 'European integration and national parliamentary oversight institutions', European Union Politics 14(2): 297-323. 